\title{
HVMANITAS
}

\section{[Recensão a] Sande, Duarte de - Diálogo sobre a Missão dos Embaixadores Japoneses à Cúria Romana}
Autor(es): $\quad$ Urbano, Carlota Miranda
Publicado por:
Faculdade de Letras da Universidade de Coimbra, Instituto de Estudos Clássicos
URL persistente:
URI:http://hdl.handle.net/10316.2/27975
DOI:
DOI:http://dx.doi.org/10.14195/2183-1718_61_28

Accessed :

26-Apr-2023 15:57:43

A navegação consulta e descarregamento dos títulos inseridos nas Bibliotecas Digitais UC Digitalis, UC Pombalina e UC Impactum, pressupõem a aceitação plena e sem reservas dos Termos e Condições de Uso destas Bibliotecas Digitais, disponíveis em https://digitalis.uc.pt/pt-pt/termos.

Conforme exposto nos referidos Termos e Condições de Uso, o descarregamento de títulos de acesso restrito requer uma licença válida de autorização devendo o utilizador aceder ao(s) documento(s) a partir de um endereço de IP da instituição detentora da supramencionada licença.

Ao utilizador é apenas permitido o descarregamento para uso pessoal, pelo que o emprego do(s) título(s) descarregado(s) para outro fim, designadamente comercial, carece de autorização do respetivo autor ou editor da obra.

Na medida em que todas as obras da UC Digitalis se encontram protegidas pelo Código do Direito de Autor e Direitos Conexos e demais legislação aplicável, toda a cópia, parcial ou total, deste documento, nos casos em que é legalmente admitida, deverá conter ou fazer-se acompanhar por este aviso. 
humanitas

\section{Vol. LXI}

IMPRENSA DA UNIVERSIDADE DE COIMBRA

COIMBRA UNIVERSITY PRESS 


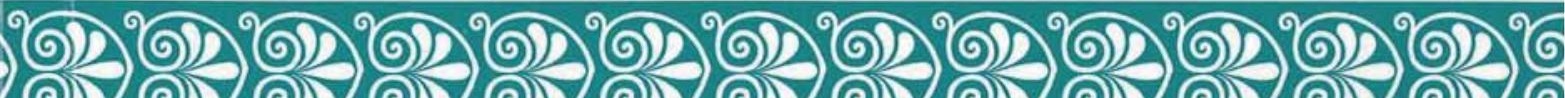

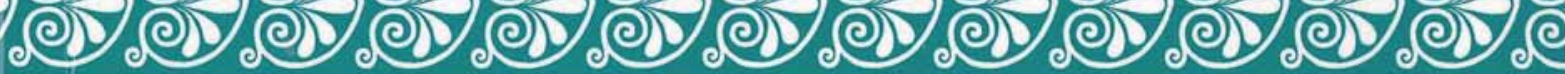

Vol. LXI 
SAnDe, Duarte de, Diálogo sobre a Missão dos Embaixadores Japoneses à Cúria Romana, 2 vol., prefácio, tradução e comentário de Américo da Costa Ramalho, estabelecimento do texto latino de Sebastião Tavares de Pinho, Coimbra, Imprensa da Universidade, Centro Científico e Cultural de Macau, 2009, 790 pp. ISBN: 978-989-8074-72-0.

Rapidamente esgotada a tradução do De Missione que o Prof. Costa Ramalho publicou em 1997 numa edição da Fundação do Oriente e da Comissão Territorial de Macau para as Comemorações dos Descobrimentos Portugueses, há muito era esperada nova publicação desta obra fundamental para o estudo da História e da Cultura de Portugal, bem como da Europa e das suas relações com o Oriente. Em boa hora a Imprensa da Universidade de Coimbra levou a cabo esta edição de uma obra que não podia de modo algum faltar na colecção Portugaliae Monumenta Neolatina, colecção coordenada cientificamente pela APENEL, Associação Portuguesa de Estudos Neolatinos, empenhada na divulgação dos textos e autores do humanismo português. Apoiaram a publicação desta obra de grande raridade e interesse para a cultura portuguesa, o Centro de Estudos Clássicos e Humanísticos, a Fundação Para a Ciência e a Tecnologia, o Programa Operacional Ciência e Inovação e a Câmara Municipal de Guimarães, terra natal de Duarte de Sande.

Em dois volumes, temos agora disponível este texto com a grande vantagem da edição bilingue, texto latino e tradução alinhados lado a lado. A edição anterior não dispunha de texto latino, agora estabelecido por Sebastião Tavares de Pinho. Tratando-se de uma obra extensa, divide-se, por isso, em dois volumes para melhor manuseamento. Certamente para não prejudicar o alinhamento dos textos (latino e português), as notas e os comentários figuram no fim de cada volume. Do ponto de vista do investigador, o recurso a este extensíssimo texto do Diálogo sobre a missão dos embaixadores japoneses à Cúria Romana encontra-se mais facilitado por dois índices de grande utilidade, um índice temático e um índice onomástico. $\mathrm{O}$ índice temático, de carácter descritivo, enuncia os assuntos tratados em cada um dos 34 colóquios e o índice onomástico, remissivo, contempla desde nomes próprios de europeus e japoneses ou mesmo de figuras míticas, até topónimos, passando por nomes de instituições.

O prefácio, da autoria do Prof. Costa Ramalho, oferece uma boa introdução à leitura da obra. Com o habitual rigor científico e conhecimento profundo do humanismo renascentista a que já nos habituou, Américo da 
Costa Ramalho não só contextualiza a obra e a embaixada que lhe serve de matéria, como a interpreta e explica na sua génese, nas suas intenções e mesmo no seu significado. Outras questões, como a da autoria da obra, ficam esclarecidas neste prefácio pelo conhecido investigador do humanismo que, em 1997, apresentou pela primeira vez a tradução que agora é de novo editada, revista e emendada.

Depois do prefácio, Sebastião Tavares de Pinho apresenta a edição e os exemplares utilizados para o estabelecimento do texto latino e informa o leitor das suas intervenções no domínio da ortografia e da pontuação, enumerando uma série de correcções e uniformizações a que procedeu. A abertura de parágrafos (que o texto de 1590 não apresentava) e a pontuação tornam o texto mais acessível ao leitor de hoje.

Seguem-se a transcrição e tradução da folha de rosto, das aprovações, das cartas dedicatórias e do índice da edição de 1590. A folha de rosto reproduz a gravura original que é significativa do contexto e do objectivo da publicação do De Missione: sentados num trono comum, Deus Pai e o Filho ladeiam o globo terrestre encimado por uma cruz. A seus pés amontoase uma multidão indeterminada de membros da Companhia de Jesus, identificados pela roupeta, que ostentam na mão uma palma, expressão iconográfica do martírio, numa clara alusão aos numerosos jesuítas, mártires da fé, que ‘conquistaram' para a Igreja o Japão.

Redigido em Latim para ter maior alcance internacional, este 'Diálogo' relata um importante feito diplomático do séc. XVI. Os jesuítas trazem à Europa, mais concretamente a Roma, para prestar obediência ao Papa, um pequeno conjunto de nobres japoneses, uma embaixada memorável, cujas notas pessoais seriam coligidas, passadas para Latim e compostas num diálogo 'para maior clareza', pela pena do Padre Duarte de Sande (cfr. p 11) que recebeu essa incumbência do Padre Alexandre Valignano. Em 1590, vinha a lume o De Missione legatorum iaponensium ad romanam curiam rebusque in Europa ac toto itinere animaduersis dialogus nos prelos da casa da Companhia de Jesus em Macau.

Mais do que o relato de um longo périplo de seis anos (1582-1588), mais que a descrição de factos ou acontecimentos, este livro fornece dados e informações interessantíssimas sobre costumes, espaços culturais e sociais das várias cidades de Portugal e da Europa por onde passaram os legados japoneses. Do diálogo entre os embaixadores e a comitiva que os guia, emergem não só esses dados relativos à Europa como dados e informações relativos ao Japão, pois esta embaixada e o texto literário que a tem 
por objecto e a divulga teria certamente por objectivos, não só revelar à Europa a civilização nipónica, como também revelar ao Japão a civilização europeia.

Os assuntos tratados nos 34 colóquios são os mais variados. Desde a organização militar, social, jurídica ou ainda religiosa da Europa, passando pela descrição de várias manifestações artísticas, de grandes cidades europeias, de universidades, mas também a comparação entre estas realidades na Europa e as equivalentes no Japão. Acontecimentos de relevo como o cerimonial das exéquias do Papa e a eleição do sucessor a que os embaixadores japoneses assistiram na sua permanência em Roma são pormenorizadamente descritos (colóquios XXIV-XXVI). A vida universitária em Coimbra e a descrição desta cidade é tema de um dos colóquios (colóquio XXXI), mas também se dedica atenção extensiva à descrição da China, do seu modo de vida, das suas religiões e à sua comparação com a Europa (colóquio XXXIV).

Em suma, temos agora mais facilitado ainda, a vários níveis, o acesso a uma obra de assinalável interesse, cuja riqueza literária, histórica e cultural está muito longe de se esgotar.

Carlota Miranda Urbano (Universidade de Coimbra)

Silva, Maria Oliveira Aparecida da, Plutarco Historiador, S. Paulo, Edusp, 2006. ISBN: 8531409209.

Prefaciado por Noberto Luiz Guarinello, professor do Departamento de História da USP, o presente volume constituiu, na sua origem, uma dissertação de doutoramento em História Social apresentada à Universidade de S. Paulo em 2007 pela investigadora.

O estudo de Maria Oliveira Aparecida da Silva coloca-nos perante um desafio inquietante e já antigo: pode Plutarco ser considerado um historiador? Onde termina o discurso filosófico e ético e começa o facto histórico?

Tomando as biografias espartanas como ponto de partida - Licurgo, Lisandro, Agesilau, Ágis IV e Cleómenes -, a A. procura demonstrar como uma análise conjunta destas Vidas permite reconstruir a história de uma cidade, Esparta, confundindo-se esta com as biografias dos seus governantes mais notáveis. Assim, a sucessão cronológica destas biografias permite 